\title{
ASPEK HUKUM NIKAH NANAU LABE PADA PERKAWINAN SUKU KAILI DI DESA BALUASE
}

\author{
Mohamad Oktafian \\ Dosen Fakultas Syariah IAIN Palu \\ email: mohamadoktafian151087@gmail.com
}

\begin{abstract}
This study aims to determine the implementation of nanau labe marriage in the marriage of the Kaili tribe in Baluse village and the underlying factors as well as to know the legal aspects of this type of marriage. This study uses a mix method of empirical juridical and normative juridical research. In this study, the authors took field data through interviews with the subjects studied regarding the problems contained in the research. Data collection in the field in this study is a characteristic of empirical legal research. In this study the authors also explore legal materials related to marriage for comparison. The use of legal materials in legal research is a characteristic of normative juridical research. Based on the results of the research conducted, the authors conclude that: first, the implementation of the nanau labe marriage in Baluse village is not only carried out for pregnant women and men who are willing to marry them, but also between the pregnant woman and the man who impregnates her. In the implementation of the nanau labe marriage, there has been a shift in customary law regarding the sanctions that apply to the perpetrators of the nanau labe marriage where the sanctions are no longer valid because they consider economic and humanitarian aspects. There are also factors that affect nanau labe marriages, namely promiscuity resulting in pregnancy, irresponsible men impregnating women, inappropriate family communication, selfish attitudes of parents and ensuring the status of the child being born. Second, nanau labe may be carried out if it is based on the opinion of the Hanafi School about the permissibility of marrying pregnant women due to adultery and marrying pregnant women not the result of adultery but must pay attention to the provisions that limit it. The nanau labe marriage does not guarantee legal certainty in the marital relationship, so there is no basis for both parties to the marriage to make demands relating to rights after divorce. Furthermore, the nanau labe marriage does not guarantee legal certainty regarding the status and rights of the child born.
\end{abstract}

Keywords: Legal Aspects, Nanau Labe Marriage, Kaili Suku Tribe 


\begin{abstract}
Abstrak
Penelitian ini bertujuan untuk mengetahui pelaksanaan nikah nanau labe pada perkawinan suku Kaili di desa Baluase dan faktor-faktor yang mendasarinya sekaligus mengetahui aspek hokum dari jenis perkawinan tersebut. Penelitian ini menggunakan mix method dari jenis penelitian yuridis empiris dan yuridis normative. Pada penelitian ini penulis mengambil data lapangan melalui wawancara kepada subjek yang diteliti terkait permasalahan yang terdapat dalam penelitian. Pengambilan data pada lapangan pada penelitian ini merupakan ciri dari penelitian hokum empiris. Dalam penelitian ini penulis juga menelusuri bahan-bahan hokum yang berkaitan dengan perkawinan untuk dilakukan perbandingan. Penggunaan bahan-bahan hokum dalam penelitian hukum merupakan ciri dari penelitian yuridis normatif. berdasarkan hasil penelitian yang dilakukan, penulis menyimpulkan bahwa: pertama, pelaksanaan nikah nanau labe di desa Baluase tidak hanya dilakukan kepada perempuan hamil dan laki-laki yang bersedia untuk menikahinya, tetapi juga dilakukan anatara wanita yang hamil tersebut dengan laki-laki yang menghamilinya. Dalam pelaksanaan nikah nanau labe telah terjadi pergeseran hokum adat mengenai sanksi yang berlakukan pada pelaku nikah nanau labe dimana sanksi tersebut sudah tidak berlaku karena mempertimbangkan aspek ekonomi dan kemanusiaan. Ada pun faktor yang mempengaruhi nikah nanau labe yaitu pergaulan bebas sehingga mengakibatkan kehamilan, laki-laki yang menghimili perempuan tidak bertanggung jawab, komunikasi keluarga yang tidak tepat, sikap egois orang tua dan memastikan status anak yang lahir. Kedua, nanau labe boleh dilakukan apabila didasarkan pada pendapat Mazhab Hanafi tentang kebolehan menikahi perempuan hamil akibat perzinahan dan menikahi perempuan hamil bukan hasil zina tetapi harus memperhatikan ketentuan-ketentuan yang membatasinya. Nikah nanau labe tidak memberikan jaminan kepastian hokum dalam hubungan perkawinan, sehingga tidak ada dasar bagi kedua belah pihak yang melakukan perkawinan untuk melakukan tuntutan yang berkaitan dengan hak-hak setelah perceraian. selanjutnya nikah nanau labe tidak memberikan jaminan kepastian hokum terhadap status dan hak-hak anak yang dilahirkan.
\end{abstract}

Kata Kunci: Aspek Hukum, Nikah Nanau Labe, Suku Kaili

\title{
A. Pendahuluan
}

Pernikahan termasuk dari sebagian anjuran agama kepada yang mampu untuk melaksanaknya, karena perkawinan dapat meminimalisasi kemaksiatan baik dalam bentuk penglihatan maupun perzinahan. Sesorang yang berkeinginan melaksanakan pernikahan akan tetapi belum 
mampu melaksanakannya dianjurkan untuk berpuasa. Dalam Islam pengertian mengenai puasa tidak sekedar dipahami untuk menahan lapar dan dan haus saja, tetapi puasa yang dimaksud bagi mereka yang belum mampu melaksanakan pernikahan adalah melakukan tindakan menahan diri dari pikiran atau hastrat seksual yang dapat menjerumuskan pada tindakan kemaksiatan.

Walau pun dengan berpuasa dianggap sebagai upaya untuk menghindari kemaksiatan, namun bukan berarti dengan berpuasa seseorang harus menghindari pernikahan sama sekali karena di dalam Islam pernikahan pun dapat bernilai ibadah. Pernikahan dapat dipahami sebagai ikatan lahir batin antara seorang pria dan wanita sebagai suami istri dengan tujuan membangun keluarga (rumah tangga) yang bahagia.

Allah menitipkan naluri kepada manusia untuk memiliki daya tarik kepada lawan jenisnya, naluri tersebut semakin menguat seiring dengan pertumbuhan usia menjadi manusia dewasa. Setelah beranjak dewasa, maka timbulah hasrat dalam dirinya untuk menyalurkan naluri seksual terhadap lawan jenisnya, agar hubungan tersebut tidak menimbulkan pertentangan serta berjalan secara harmonis, maka agama mengaturnya dalam hukum perkawinan. Perkawinan mengandung aspek akibat hukum yaitu saling mendapat hak dan kewajiban serta bertujuan untuk mengadakan hubungan yang dilandasi tolong menolong. Karena perkawinan termasuk pelaksanaan agama, maka didalamnya terkandung adanya tujuan atau maksud mengharapkan keridhaan Allah SWT.

Dalam al-Qur'an dinyatakan mengenai naluri manusia untuk memiliki pasangan hidup dan memiliki keturunan berpasang-pasangan sebagaimana firman Allah dalam surat an-Nisa' ayat 1 :

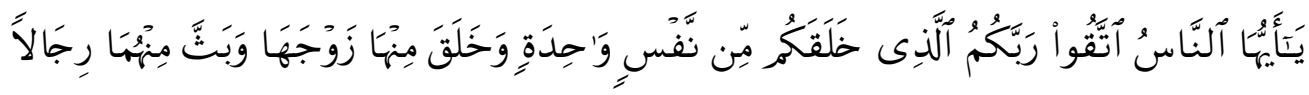

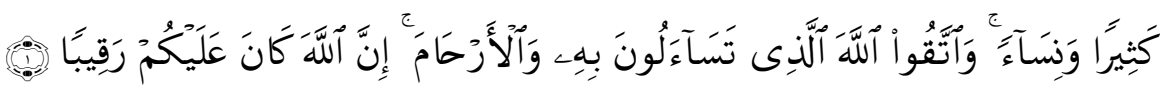




\section{Terjemahannya:}

Hai sekalian manusia, bertakwalah kepada Tuhan-mu yang telah menciptakan kamu dari diri yang satu, dan dari padanya Allah menciptakan istrinya, dan dari pada keduanya Allah memperkembang biakkan lakai-laki dan perempuan yang banyak dan bertakwalah kepada Allah yang dengan nama-Nya kamu saling meminta satu sama lain, dan peliharalah hubungan silaturrahim. Sesungguhnya Allah selalu menjaga dan mengawasi kamu. ${ }^{1}$

Islam menganjurkan perkawinan bagi yang telah mampu melaksanakannya sehingga perbuatan tersebut memiliki nilai ibadah. Nikah dapat bernilai ibadah karena perbuatan tersebut merupakan upaya untuk menghindarkan seseorang dari perbuatan maksiat yang dilarang Allah SWT. Rasullah saw bersabda:

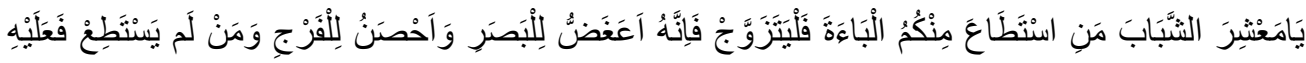

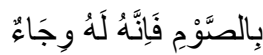

Terjemahannya:

wahai para pemuda, barangsiapa diantara kamu telah mampu memikul biaya perkawinan hendaklah kawin, sebab perkawinan itu lebih mampu menundukan mata dan menjaga kehormatanmu, barangsiapa belum mampu hendaklah berpuasa, sebab puasa itu baginya akan mengekan syahwat (H.R. Imam Bukhari). ${ }^{2}$

Al-Qur'an dan Sunnah merupakan pedoman bagi umat Islam dalam melakukan suatu perbuatan termasuk membangun rumah tangga, rujukan penyusunan Kompilasi Hukum Islam yang berkaitan dengan perkawinan juga mengacu pada kedua pedoman tersebut. Keberadaan Kompilasi Hukum Islam ini sebagai tindak lanjut dari ketentuan yang mengatur tentang perkawinan bagi masyarakat Indonesia yang terdapat dalam Undang-Undang Nomor 1 tahun 1974 tentang Perkawinan.

Dalam Pasal 2 dan 3 Kompilasi Hukum Islam disebutkan bahwa pernikahan adalah akad yang sangat kuat untuk menaati perintah Allah h. 114.

${ }^{1}$ Departemen Agama Republik Indonesia, Al-Qur'an dan Terjemahnya, (Jakarta: al Hidayah, 2002),

${ }^{2}$ Al Imam Abu Abdullah Muhammad bin Ismail Al Bukhari, Shahih Bukhari Juz 1, Terj. Achmad Sunarto, dkk, Tarjamah Shahih Bukhari Jilid 1, (Semarang: CV. Asy Syifa', 1991), h. 4-5. 
dan melaksanakannya merupakan ibadah, yang bertujuan untuk mewujudkan kehidupan rumah tangga yang sakinnah, mawaddah dan rahmah. ${ }^{3}$ Perkawinan merupakan kehendak manusia yang bertujuan untuk pemenuhan kebutuhan jesmani dan rohani, untuk itu perkawinan harus dilaksanakan secara sah agar dapat melakukan hubungan secara halal dan terhormat, serta diharapkan memperoleh keturunan yang sah dalam masyarakat sehingga kelangsungan hidup dalam keluarga dan keturunan dapat berlangsung secara bersih dan jelas.

Ketentuan pernikahan sebagaimana yang diatur oleh dalam Kompilasi Hukum Islam seharusnya dijadikan rujukan bagi setiap muslim di Negara Indonesia yang akan melaksanakan perkawinan, tetapi di masyarakat ditemukan bentuk perkawinan yang sifatnya tidak memiliki kepastian hukum karena sifatnya bertentangan atau tidak memenuhi persyaratan dalam hukum positif di negara kita seperti nikah nikah mut'ah dan nikah kawin kontrak (nikah siri).

Kawin kontrak umumnya banyak terjadi di daerah-daerah yang banyak kegiatan industrialisasi nya, khususnya kegiatan industry yang banyak mendatangkan tenaga kerja dari luar negeri seperti daerah puncak (Jawa Barat), Jepara (Jawa Tengah) serta Singkawang (Kalimantan Barat). ${ }^{4}$ Sedangkan nikah siri atau nikah dibawah tangan adalah suatu pernikahan atau perkawinan yang dilakukan oleh calon mempelai laki-laki kepada calon mempelai perempuan tanpa dicatat oleh Pegawai Pencatat Nikah dan tidak mempunyai akta nikah. ${ }^{5}$

Selain permasalahan perkawinan pada dua bentuk perkawinan yang ada di atas, dalam kondisi tertentu juga terdapat permasalahan yang berkaitan dengan perkawinan wanita yang hamil di luar nikah. Perkawinan pada wanita hamil diluar nikah disisi lain dianggap sebagai solusi untuk

\footnotetext{
${ }^{3}$ Kompilasi Hukum Islam, h. 228.

${ }^{4}$ Muhyidin, Nikah Mut'ah (kawin kontrak) dalam Perspektif Hukum Positif Indonesia Serta Akibat Hukum Atas Harta Perkawinan dan Harta Waris.

(http://ejournal2.undip.ac.id/index.php/dplr/article/download/8180/4302\#: :text+kawin\%20kontrak\%20merupaka n\%20perkawinan\%20yang, 1\%20Tahun\%201974\%20tentang\%20Perkawinan) diakses pada tanggal 19 Januari 2021

${ }^{5}$ Zainuddin Ali, Hukum Perdata Islam di Indonesia (Jakarta: Sinar Grafika, 2007), h. 7
} 
menutupi aib keluarga sekaligus sebagai bentuk pertanggungjawaban laki-laki yang telah menghamilinya. Pernikahan pada wanita hamil tersebut menjadi awal bagi keduanya untuk membina keluarga pada tahap berikutnya, tetapi dalam kondisi tertentu pengurusan perkawinan pada wanita hamil tidak berakhir seperti apa yang diharapkan dimana kedua mempelai dapat menjalani rumah tangga seperti harapan pernikahan pada umumnya yaitu membina rumah tangga.

Pada masyarakat suku Kaili terdapat suatu bentuk pekawinan yang disebut dengan nikah nanau labe. Nikah nanau labe adalah istilah yang digunakan suku kaili terhadap prosesi nikah turun. Dikatakan nikah nanau labe sebagai nikah turun karena setelah prosesi ijab kabul dalam pernikahan dilaksanakan maka mempelai laki-laki akan turun atau meninggalkan rumah mempelai wanita sebagai simbol putusnyanya hubungan perkawinan. Nikah nanau labe merupakan bentuk khusus dari pernikahan wanita yang hamil di luar nikah. Pada perkawinan wanita yang hamil di luar nikah kesempatan untuk menjalani kehidupan rumah tangga masih sangat besar, tetapi pada nikah nanau labe pernikahan sudah tidak lagi bertujuan untuk menjalani dan membina rumah tangga, melainkan hanya sekedar menutupi aib atas kehamilan sekaligus memperjelas status anak yang nantinya akan dilahirkan.

\section{B. Tinjauan Umum tentang Perkawinan}

\section{Pengertian nikah dan perkawinan}

Dalam Kamus Besar Bahasa Indonesia kata nikah memiliki arti sebagai perjanjian antara laki-laki dan perempuan untuk bersuami istri, ${ }^{6}$ kata nikah bersumber dari bahsa Arab, yaitu nikahun yang merupakan kata dasar dari kata (nakaha) sebagai kata kerja yang memiliki arti mengumpulkan, saling memasukan dan digunakan untuk arti bersetubuh (wathi), kemudian diterjamahkan dalam Bahasa Indonesia sebagai Departemen Pendidikan dan Kebudayaan, Kamus Besar Bahasa Indonesia (Jakarta:
Kencana,1994), h. 614 
perkawinan. Menurut bahasa, kata nikah berarti adh-dhammu wattadaakhul yang artinya bertindih dan memasukkan. Kata nikah juga diartikan dengan adh-dhammu wal jamu' yang artinya bertindih dan berkumpul. Secara istilah nikah adalah suatu akad yang menyebabkan kebolehan bergaul antara seorang laki-laki dan perempuan dan saling menolong antara keduanya serta menentukan batas hak dan kewajibannya diantara keduanya. ${ }^{7}$

Pada bagian ini penulis akan mengemukakan beberapa pengertian mengenai pernikahan atau perkawinan sebagai acuan teori penelitian yang akan dilaksanakan:

a. Sedang R. Abdul Djamali dalam bukunya yang berjudul Hukum Islam, berdasarkan ketentuan kurikulum konsorsium ilmu hukum berpendapat bahwa istilah perkawinan menurut hukum Islam adalah nikah atau ziwaj. Kedua istilah ini dilihat dari arti katanya dalam bahasa Indonesia ada perbedaan, sebab kata nikah berarti hubungan seks antara suami istri, sedangkan ziwaj berarti kesepakatan antara seorang pria dan seorang wanita yang mengikatkan diri dalam hubungan suami istri untuk mencapai tujuan hidup dalam melaksanakan ibadah kebaktian kepada Allah ${ }^{8}$.

b. Anwar Harjono mengatakan pernikahan adalah suatu perjanjian suci antara seorang laki-laki dengan seorang perempuan untuk membentuk keluarga bahagia 9 .

c. Ahmad Azhar Basyir dalam sebuah bukunya yang berjudul Hukum Perkawinan Islam berpendapat bahwa perkawinan menurut Islam adalah suatu akad atau perikatan untuk menghalalkan hubungan kelamin antara laki-laki dan perempuan dalam rangka mewujudkan kebahagiaan hidup keluarga, yang diliputi rasa ketentraman serta kasih sayang dengan cara diridhoi oleh Allah SWT ${ }^{10}$.

Perkawinan merupakan cara yang dipilih Allah sebagai jalan bagi manusia untuk beranak pinak, berkembang biak dan melastarikan hidupnya setelah masing-masing pasangan siap melakukan perannya yang positif dalam mewujudkan tujuan perkawinan. Allah tidak menjadikan

\footnotetext{
2000), h.11-13

Rahmat Hakim, Hukum Perkawinan Islam untuk IAIN, STAIN, PTAIS (Bandung: CV Pustaka Setia,

${ }^{8}$ R. Abdul Djamali, Hukum Islam (Bandung: Mandar Maju, 2000), h. 77-78

${ }^{9}$ Ibid, h. 47

${ }^{10}$ Ahmad Azhar Basyir, Hukum Perkawina Islam (Yogyakarta, UII Pres, 2000), h.14
} 
manusia seperti makhluk lainnya yang hidup bebas mengikuti nalurinya dan berhubungan secara anarkhi tanpa aturan. Demi menjaga kehormatan dan martabat kemuliaan manusia, Allah mengadakan hukum sesuai dengan martabatnya, sehingga hubungan antara laki-laki dan perempuan diatur secara terhormat dan berdasarkan rasa saling meridhai, dengan upacara ijab Kabul sebagai lambing adanya rasa ridha-meridhai dan dengan dihadiri para saksi yang menyaksikan bahwa pasangan lakilaki dan perempuan itu telah saling terikat. Bentuk perkawinan ini telah memberikan jalan yang aman pada naluri seks, memelihara keturunana dengan baik dan menjaga kaum perempuan agar tidak laksana rumput yang biasa dimakan oleh binatang ternak dengan seenaknya. Pergaulan suami istri menurut ajaran Islam diletakan dibawah naluri keibuan dan kebapaan sebagai lading yang baik yang nantinya menumbuhkan tumbuhtumbuhan yang baik dan menghasilkan buah yang baik pula. ${ }^{11}$

Berdasarkan pengertian di atas kita dapat mengetahui bahwa pernikahan merupakan sarana agama Islam untuk menghalalkan hubungan antara dua lawan jenis yang bukan mahram ke dalam satu kehidupan bersama untuk membina rumah tangga melalui akad.

2. Asas perkawinan

Dalam perkawinan terdapat asas-asas yang menjadi prinsip sekaligus sebagai indikator tercapai tujuan pernikahan. Ada pun prinsipprinsip yang dimaksud adalah sebagai berikut: ${ }^{12}$

1. Masing-masing suami dan istri mempunyai tekad hanya mempunyai seorang sebagai pasangan dalam kehidupan rumah tangga

2. Ada kerelaan dan persetujuan antara suami dan istri

3. Perkawinan untuk selamanya

4. Anggota keluarga memenuhi dan melaksanakan norma agama

${ }^{11}$ Sayyid Sabiq, Fiqh al-Sunnah (Beirut: Dar al-Fikr, 1983), cet. 4 jilid 2, h. 5

${ }^{12}$ Khoiruddin Nasution, Hukum Perdata (keluarga) Islam Indonesia dan Perbandingan Hukum Perkawinan di Dunia Muslim (Yogyakarta: ACAdeMIA), h. 233 
5. Kehidupan rumaht tangga berjalan secara musyawarah dan demokrasi

6. Berusaha menciptakan rasa aman, nyaman dan tentram dalam kehidupan keluarga

7. Menghindari terjadinya kekerasan

8. Bahwa hubungan suami istri adalah hubungan partnership, yang berarti saling membutuhkan, saling menolong, saling membantu dalam menyelesaikan semua urusan rumah tangga

9. Ada keadilan

10. Terbangun komunikasi antar anggota keluarga

Asas-asas yang ada di atas menjadi rujukan atau semangat dalam pembuatan aturan yang berkaitan dengan perkawinan sekaligus menjadi cita-cata yang ingin dicapai dari perkawinan itu sendiri, sekalipun asas bukan sebuah norma hukum tetapi keberadaannya sangat menentukan dari isi sebuah aturan.

\section{Dasar hukum perkawinan}

Secara garis besar para ulama Ushul Fiqh membagi hukum pada dua macam, yaitu hukum taklifi dan hukum wadh'i. hukum taklifi menurut ulama ushul figh adalah ketentuan-ketentuan Allah dan rasul-Nya yang berhubungan dangan perbuatan orang mukalaf, baik dalam perintah, anjuran melakukan, larangan, anjuran untuk tidak melakukan, atau dalam bentuk memberikan kebebasan memilih untuk berbuat atau tidak berbuat. Sedangkan yang dimaksud dengan hukum wadh'i ialah ketentuanketentuan hukum yang mengatur tentang sebab, syarat dan mani' (sesuatu yang menjadi penghalang kecakapan untuk melakukan hukum taklifi), ${ }^{13}$ ada pun status hukum pernikahan menurut Islam adalah sebagai berikut: ${ }^{14}$

\section{Mubah}

\footnotetext{
${ }^{13}$ Satria Efendi, Ushul Fiqh (Jakarta: Kencana, 2005), h. 41

${ }^{14}$ Amir Syarifuddin, Garis-Garis Besar Fiqih (Jakarta: Kencana Prenada Media,2003), h. 79
} 
Hukum mubah bagi orang-orang yang pada dasarnya belum ada dorongan untuk kawin dan perkawinan itu tidak akan mendatangkan kemudharatan apa-apa pada siapapun.

2. Sunnah

Hukum Sunnah bagi orang-orang yang telah berkeinginan untuk kawin, telah mampu untuk dalam biaya untuk melangsungkan perkawinan.

3. Wajib

Wajib bago orang-orang yang berkeinginan untuk kawin, telah mampu untuk biaya melangsungkan perkawinan dan khawatir akan terjerumus pada kemaksiatan jika tidak kawin.

4. Makruh

Hukum makruh bagi orang-orang yang belum berkeinginan untuk kawin, belum mampu untuk kawin atau belum mampu dalam biaya untuk melangsungkan perkawinan, begitu pula apabila ia telah mampu dalam biaya untuk melangsungkan perkawinan namun fisiknya mengalami cacat seperti impoten, berpenyakitan tetap, tua Bangka atau kekurangan fisik lainnya.

5. Haram

Hukum haram bagi orang-orang yang telah berkeinginan untuk kawin, telah mampu untuk kawin dan telah mampu dalam biaya untuk melangsungkan perkawinan akan tetapi memiliki tujuan untuk kemudharatan atau bagi orang-orang yang tidak akan dapat memenuhi ketentuan syara' untuk melakukan perkawinan atau ia yakin perkawinan itu tidak akan mencapai tujuan syara' sedangkan ia meyakini perkawinan itu akan merusak kehidupan pasangannya.

Bagi warga Negara Indonesia ketentuan yang mengatur pelaksanaan pernikahan diatur dalam Undang-Undang Nomor 1 Tahun 1974 Tentang Perkawinan dan Kompilasi Hukum Islam bagi warga negara Indonesia yang beragama Islam. Dalam Undang-Undang Perkawinan Pasal 1 disebutkan bahwa perkawinan ialah ikatan lahir batin antara 
seorang pria dengan seorang wanita sebagai suami istri dengan tujuan membentuk keluarga (rumah tangga) yang bahagia dan kekal berdasarkan Ketuhanan Yang maha Esa. Selanjutnya pada Pasal 2 disebutkan bahwa perkawinan adalah sah, apabila dilakukan menurut hukum masing-masing agamanya dan kepercayaannya itu. Ketentuan yang terdapat pada Pasal 2 Undang-Undang Perkawinan inilah yang menjadi rujukakan pelaksanaan perkawinan bagi umat muslim Indonesia yang di uraikan dalam Kompilasi Hukum Islam. Pada Pasal 2 Kompilasi Hukum Islam disebutkan bahwa perkawinan menurut hukum Islam adalah pernikahan, yaitu akad yang sangat kuat atau mitsaaqon gholiidhan untuk menaati perintah Allah dan melaksanakannya merupakan ibadah.

3. Syarat dan rukun perkawinan

Pada saat akan dilaksanakannya perkawinan maka seorang penghulu atau wali yang akan menikahkan harus memperhatikan ketentuan mengenai rukun dan syarat dalam perkawinan, karena rukun dan syarat inilah yang akan menentukan sah atau tidaknya suatu perkawinan. Yang dimaksud dengan rukun adalah sesuatu yang harus ada sebagai penentu sah atau tidaknya suatu amaliah (ibadah) dan sesuatu itu termasuk dalam rangkaian pekerjaan itu, seperti membasuh tangan hingga siku pada saat berwudhu dan membaca al Fatihah ketika shalat dan dalam hal perkawinan semisal adanya ijab dan kabul. Sedangkan yang dimaksud dengan syarat yaitu sesuatu yang harus ada yang menentukan sah dan tidaknya suatu pekerjaan (ibadah), tetapi sesuatu yang dimaksudkan tersebut tidak termasuk dalam rangkaian pekerjaan itu seperti menutup aurat untuk shalat, dalam hal perkawinan semisal calon pengantin laki-laki dan perempuan harus beragama Islam.

Pasal 14 Kompilasi Hukum Islam disebutkan bahwa ketentuan mengenai rukun nikah adalah sebagai berikut:
a. Calon suami
b. Calon istri
c. Wali nikah 
d. Dua orang saksi dan

e. ljab dan kabul

Sebagaimana disebutkan di atas bahwa dalam pelaksanaan perkawinan selain memenuhi kelengkapan yang berkaitan rukun juga harus memastikan ketentuan mengenai syarat pelaksanaannya. Adapun syarat yang dimaksud adalah sebagai berikut: ${ }^{15}$

a. Syarat-syarat suami

1. bukan mahram dari calon istri

2. tidak terpaksa

3. jelas orangnya

4. beragama Islam

5. tidak terdapat halangan perkawinan

b. Syarat-syarat istri

1. beragama Islam

2. tidak terpaksa

3. jelas orangnya

4. tidak terdapat halangan perkawinan

c. Syarat-syarat wali

1. Baligh

2. waras akalnya

3. tidak terpaksa

4. adil

5. tidak terdapat halangan perwaliannya

d. Syarat-syarat saksi

1. laki-laki

2. waras akalnya

3. baligh

4. adil

5. dapat mendengar dan melihat

6. tidak dipaksa

${ }^{15}$ H.S.A. Al Hamdani, Risalah Nikah (cet 3; Jakarta: Pustaka Aman, 1998), h. 30-31 
7. memahami bahasa yang dipergunakan dalam ijab kabul atau dapat mengerti maksud akad

e. Syarat-syarat ijab kabul

1. adanya pernyataan mengawinkan dari wali dan pernyataan penerimaan dari calon mempelai

2. memakai kata-kata nikah, tazwij atau terjemahan dari kedua kata tersebut

3. antara ijab dan kabul bersambungan

4. antara ijab dan kabul jelas maksudnya

5. majelis ijab dan kabul itu harus dihadiri minimum empat orang yaitu calon mempelai, wali dari mempelai wanita dan dua orang saksi

Ketentuan yang mengatur perkawinan di Indonesia ditetapkan dalam Undang-Undang Nomor 1 Tahun 1974 tentang perkawinan yang selanjutnya aturan yang berkaitan dengan pencatatan perkawinan diatur dalam Peraturan Pemerintah Republik Indonesia Nomor 9 Tahun 1975 tentang Pelaksanaan Undang-Undang Nomor 1 Tahun 1974 tentang Perkawinan. Uraian tentang perkawinan bagi warga negara Indonesia yang beragama Islam diatur dalam Kompilasi Hukum Islam berdasarkan Instruksi Presiden Republik Indonesia Nomor 1 Tahun 1991 yang kemudian ditindaklanjuti oleh Keputusan Menteri Agama Republik Indonesia sebagai pelaksanaan dari peraturan tersebut.

Uraian tentang rukun dan syarat nikah dijabarkan dalam BAB IV Kompilasi Hukum Islam. Pada Pasal 15 di sebutkan bahwa untuk kemaslahatan keluarga dan rumah tangga, perkawiana hanya boleh dilakukan calon mempelai yang telah mencapai umur yang ditetapkan dalam Pasal 7 Undang-Undang Nomor 1 Tahun 1974, yakni calon suami sekurang-kurangnya berumur 19 tahun dan calon istri sekurangkurangnya berumur 16 tahun. Ketentuang mengenai batas usia seseorang melakukan perkawinan sebagaimana diatur dalam Pasal tersebut telah diubah berdasarkan Undang-Undang Republik Indonesia Nomor 16 tahun 
2019 Tentang Perubahan Atas Undang-Undang Nomor 1 Tahun 1974 Tentang Perkawinan. Pada Undang- Undang tersebut disebutkan bahwa perkawinan hanya diizinkan apabila pria dan wanita sudah mencapai umur 19 tahun, adapun jika terjadi penyimpangan terhadap batas usia tersebut atau calon mempelai belum mencapai batas usia sebagaimana ditentukan oleh Undang-Undang maka akan diberikan dispensasi oleh Pengadilan berdasarkan alasan sangat mendesak dan bukti yang disampaikan oleh orang tua calon mempelai. Artinya dalam perkawinan negara memberikan kebebasan seseorang (calon mempelai) untuk berkeluarga dan melanjutkan keturunan tetapi disisi lain negara juga wajib memberikan perlindungan dan kemaslahatan bagi pihak yang akan melangsungkan perkawinan. Ada pun berkaitan dengan batas usia kawin sebagaimana yang diataur dalam Undang-Undang Nomor 16 Tahun 2019 tersebut didasarkan pada asas kesetaraan laki-laki dan perempuan yang memiliki kedudukan yang sama didepan hukum.

Pada Pasal 16 Kompilasi Hukum Islam disebutkan bahwa perkawinan didasarkan atas dasar persetujuan calon mempelai. Bentuk persetujuan calon mempelai wanita dapat berupa pernyataan tegas dan nyata dengan tulisan, lisan atau isyarat tetapi dapat juga berupa diam dalam arti selama tidak ada penolakan yang tegas. Bahkan sebelum dilangsungkannya perkawinan Pegawai Pencatat Nikah menanyakan terlebih dahulu kepada calon mepelai mengenai persetujuannya dan dalam hal perkawinan tidak disetujui oleh salah seorang mempelai maka perkawinan tidak dapat dilangsungkan. Bagi calon suami atau istri yang akan melangsungkan pernikah tentunya tidak terdapat halangan perkawinan. Halangan perkawinan yang maksudkan berkaitan dengan larangan kawin yang disebabkan adanya pertalian nasab, pertalian kerabat semenda, pertalian susuan dan larangan tertentu lainnya seperti salah seorang mempelai tidak beragama Islam, wanita yang menjalani masa iddah, menikahi wanita yang memiliki pertalian nasab atau susuan dengan istri, menikahi lebih dari empat orang istri dan menikahi wanita 
bekas istri yang telah ditalak tiga kali atau di li'an dengan ketentuan larangan tersebut akan gugur jika wanita tersebut telah menikah (ba'da dukhul) dan bercerai dengan pria lain serta telah selesai masa iddahnya.

Pada Pasal 19 juga diatur ketentuan yang berkaitan dengan wali nikah yang merupakan rukun yang harus dipenuhi calon mempelai wanita yang bertindak untuk menikahkannya. Pada Pasal 20 disebutkan bahwa yang bertindak sebagai wali nikah ialah seorang laki-laki yang memenuhi syarat hukum Islam, yakni muslim, akil dan baligh.ada pun wali nikah tersebut terdiri dari wali nasab dan wali hakim. Wali nasab adalah mereka yang memiliki susunan kekerabatan dari mempelai wanita dari garis lakilaki, seperti ayah, kakek, kakek dari pihak ayah, saudara laki-laki kandung atau saudara laki-laki seayah dan keturunan mereka, saudara laki-laki kadung ayah atau saudara seayah dan keturunan laki-laki mereka, saudara laki-laki kandung kakek, saudara laki-laki seayah kakek serta lakilaki dari pihak mereka. Kedudukan wali nasab lebih diutamakan dari wali hakim, karena wali hakim baru dapat bertindak sebagai wali nikah apabila wali nasab tidak ada, tidak diketahui tempat tinggalnya atau enggan.

Selain keadaan kedua calon mempelai dan wali nikah, pada Pasal 24 diatur ketentuan mengenai saksi nikah yang terdiri dari dua orang dan yang ditunjuk menjadi saksi dalam akad nikah ialah seorang yang tidak terganggu ingatan, tidak tuna rungu atau tuli. Selanjutnya dalam pelaksanaan akad nikah ijab dan kabul antara wanita dan calon mempelai pria harus jelas beruntun dan tidak berselang waktu sebagaimana disebutkan pada Pasal 27.

\section{Akibat hukum perkawinan}

Perkawinan merupakan perbuatan hukum yang akibat hukumnya dikehendaki oleh subjek hukum, sehingga setelah selesainya prosesi ijab dan kabul dalam akad nikah maka kedua mempelai resmi menjadi pasangan suami istri yang terntunya pada keduanya melekat aspek hak dan kewajiban sebagai suami istri, hak dan kewajiban mengenai pemeliharan anak dan aspek hukum lainnya. Kedudukan suami istri 
sebagaimana diatur pada Pasal 31 Undang-Undang Nomor 1 Tahun 1974 Tentang Perkawinan juga di atur dalam Pasal 79 Kompilasi Hukum Islam, adapun kedudukan suami istri dalam ketentuan tersebut adalah sebagai berikut:

1. hak dan kedudukan istri adalah seimbang dengan hak dan kedudukan suami dalam kehidupan rumah tangga dan pergaulan hidup dalam masyarakat.

2. Masing-masing pihak berhak untuk melakukan perbuatan hukum.

3. Suami adalah kepala rumah tangga dan istri adalah ibu rumah tangga.

Pasal 33 Undang-Undang Perkawinan menyatakan bahwa suami istri wajib saling mencintai, hormat menhormati, setia dan memberi bantuan lahir batin yang kepada yang lain. Dalam Kompilasi Hukum Islam diatur dalam Pasal 77 disebutkan:

1. Suami istri memikul kewajiban yang luhur untuk menegakkan rumah tangga yang sakinah, mawadah dan rahmah yang menjadi sendi dasar dari susunan masyarakat.

2. Suami istri wajib saling cinta mencintai, hormat menghormati, setia dan memberi bantuan lahir batin yang satu kepada yang lain.

3. Suami istri memikul kewajiban untuk mengasuh dan memelihara anak-anak mereka, baik mengenai pertumbuhan jesmani, rohani maupun kecerdasannya dan pendidikan agamanya.

4. Suami istri wajib memelihara kehormatannya.

5. Jika suami istri melalaikan kewajibannya, masing-masing dapat mengajukan gugatan kepada Pengadilan Agama.

Selanjutnya ketentuan mengenai kewajiban suami istri diatur dalam Pasal 80 Kompilasi Hukum Islam, adapun kewajiban yang dimaksud adalah sebagai berikut:

1. Suami adalah pembimbing bagi istri dan rumah tangganya, akan tetapi mengenai hal-hal urusan rumah tangga yang penting-penting diputuskan secara bersama-sama. 
2. Suami wajib melindungi istrinya dan memberikan segala sesuatu keperluan hidup berumah tangga sesuai dengan kemampuannya.

3. Suami wajib memberikan pendidikan agama kepada istrinya dan memberikan kesempatan belajar pengetahuan yang berguna dan bermanfaat bagi agama, nusa dan bangsa.

4. Sesuai dengan penghasilan suami menanggung:

a. Nafkah, kiswah, dan tempat kediaman bagi istri.

b. Biaya rumah tangga, biaya perawatan dan biaya pengobatan bagi istri dan anak.

c. Biaya pendidikan bagi anak.

5. Kewajiban suami terhadap istrinya seperti tersebut pada ayat (4) huruf a dan $b$ di atas mulai berlaku sesudah ada tamkin sempurna dari istrinya.

6. Istri dapat membebaskan suaminya dari kewajiban terhadap dirinya sebagaimana tersebut pada ayat (4) huruf a dan b.

7. Kewajiban suami sebagaimana dimaksud pada ayat (5) gugur apabila istri nusyuz.

\section{Hasil Penelitian dan Pembahasan}

1. Pelaksanaan Nikah Nanau Labe Pada Perkawinan Suku Kaili di Desa Baluase

Hukum adat merupakan system hukum yang dikenal dalam tantanan lingkungan social, sehingga dapat dikatakan, jika system sosial merupakan titik tolak dalam membahasa hukum adat di Indonesia. Istilah hukum adat ini juga diperkenalkan dikalangan banyak orang yang lazimnya mereka sebut "adat" saja. Kata "adat" berasal dari bahasa Arab yang berarti kebiasaan. Berdasarkan hal ini, dapat dilihat dari perkembangan hidup manusia yang diberi akal pikiran oleh Tuhan dalam berperilaku. Perilaku yang secara terus menerus dilakukan perorangan menimbulkan kebiasaan pribadi. ${ }^{16}$

${ }^{16}$ Suriyaman Mustari, Hukum Adat Dahulu Kini dan Akan Datang (Jakarta: Kencana, 2014), h. 2 
Interaksi anatara-sesama manusia yang dilakukan secara berulangulang akan memberi pengaruh terhadap tingkah laku bagi individu lainnya, sehingga dalam proses berikutnya sesuatu yang dilahirkan dari bentuk interaksi tersebut akan menjadi sesuatu yang dapat diterima di masyarakat sebagai suatu hubungan sosial. Apabila hubungan soasial dilakukan secara sistematis, maka hubungan sosial tersebut akan menjadi sebuah sistem sosial atau tatanan yang terdapat masyarakat itu sendiri.

Dalam kaitannya dengan perkawinan bagi sebagian besar umat muslim Indonesia, kedudukan adat turut manjadi bagian dari proses pelaksanaan perkawinan walaupun bukan termasuk dalam bagian yang menentukan sah atau tidaknya hubungan pernikahan. Dengan demikian pada dasarnya hukum perkawinan bagi masyarakat Indonesia yang beragama Islam kebanyakan merupakan perpaduan anatara hukum Islam dan hukum adat.

Aturan-aturan hukum adat perkawinan di beberapa daerah yang ada di Indonesia memiliki corak yang berbeda-beda tentunya hal ini dipengaruhi oleh sifat atau keragaman yang dimiliki bangsa Indonesia seperti suku, agama dan kepercayaan yang ada didalamnya. Pada masyarakat Sinjai terdapat salah satu bentuk perkawinan yang disebut dengan Passampo Siri' atau pernikahan penutup malu. perkawinan Passampo Siri' dilakukan akibat hamilnya seorang wanita di luar nikah tetapi laki-laki yang menghamilinya tidak bertanggung jawab atas perbuatannya sehingga dicarikanlah laki-laki yang bersedia untuk menikahinya tetapi dengan ketentuan setelah dilaksanakan ijab kabul mereka tidak tinggal bersama-sama untuk membina keluarga(cerai). ${ }^{17}$

Perkawinan Passampo Siri' sepintas memiliki kemiripan dengan nikah nanau labe terutama berkaitan dengan hamilnya seorang wanita yang kemudian dinikahkan dengan laki-laki lain yang bukan ayah biologis dari anak yang di kandung oleh perempuan tersebut. Pada nikah nanau

${ }^{17}$ Abdul Hamid, Kahi' Pura Sebagai Perkawinan Passampo Siri' di Desa Biji Nangka Kecamatan Sinjai Borong Kabupaten Sinjai. https://ojs.unm.ac.id/tomalebbi/article/view/3663/2079 diakses pada tanggal 19 Januari 2021 
labe terkadang laki-laki yang diduga menghamili seorang perempuan walaupun dirinya menyangkal bahwa itu bukan anak biaologisnya tetapi dia siap untuk dinikahkan tetapi dengan persyaratan selesai nikah dia langsung turun dari rumah perempuan. Selanjutnya nikah nanau labe juga dapat terjadi ketika perempuan hamil tersebut dinikahkan dengan laelaki yang menghamilinya tetapi karena hubungan tersebut tidak mendapat dukungan dari keluarga perempuan maka untuk perkawinan berakhir dengan nikah nanau labe. Biasanya nikah nanau labe pada bentuk yang ketiga ini dilatarbelakangi oleh ketersinggungan atau kesalahpahaman keluarga. Keterangan lebih lanjut mengenai bentuk dan pelaksanaan nikah nanau labe dapat dilihat dari penjelasan yang disampaikan oleh salah satu orang tua adat suku kaili yang ada didesa Baluase yang mengatakan bahwa:

Nikah nanau labe yaitu perempuan tersebut memberi tahu pada orang tuanya atau pun pada Imam bahwa dirinya telah "dirugikan" hamil oleh laki-laki yang dia maksud, sedangkan laki-laki yang dimaksud perempuan itu menyangkal dan mengatakan saya betulbetul tidak mengapa-apakan dia, kalau pun saya dinikahkan dengan dia tapi dengan penentuan selesai akad nikah saya langsung turun, istilahnya saya hanya mengamankan saja. Dalam masalah yang demikian pengakuan perempuan itu termasuk orang yang mudah dipercaya perkataannya. Yang termasuk juga nikah nanau labe yaitu ketika nyata-nyata si perempuan hamil akibat hubungannya dengan kekasihnya tetapi karena orang tua dari pihak perempuan tidak menyukai laki tersebut (saba nepohayu karena inggu da langgai) maka sebagai bentuk tanggung jawab atas kehamilan tersebut maka pernikahan tetap dilaksanakan tetapi setelah akad nikah laki-laki turun meninggalkan rumah berdasarkan keinginan dari orang tua perempuan. Nikah nanau labe juga termasuk ketika si perempuan hamil akibat hubungan dengan kekasihnya tetapi laki-laki tersebut meninggalkan perempuan tersebut tanpa diketahui keberadaanya sehingga untuk membayar rasa malu keluarga maka wanita itu dinikahkan dengan laki-laki yang menjadi keluarga. ${ }^{18}$ 
Keterangan yang sama juga disampaikan oleh salah satu tokoh agama yang ada di desa Baluase mengenai latar belakang terjadinya nikah nanau labe:

Kadang-kadang ada juga yang terjadi ketika si laki-laki mengaku bahwa hubungan badan tersebut tidak hanya dilakukan oleh dirinya sendiri tetapi juga dilakukan oleh laki-laki lain. Pada saat perempuan tersebut hamil, dia menunjuk salah seorang dari lakilaki tersebut sebagai pelakunya sehingga si laki-laki yang dituduhkan tersebut mengatakan bersedia untuk menikah tetapi dengan persyaratan nikah nanau labe. ${ }^{19}$

Berdasarkan keterangan tersebut dapat diketahui bahwa pada masyarakat suku Kaili terdapat tiga bentuk rincian dari praktik nikah nanau labe. Ada pun pelaksanaan nikah nanau labe di lakukan secara sederhana tidak seperti perkawinan pada umumnya yang mengundang orang banyak dan melaksanakan rentetan adat dalam perkawinan. Suku kaili yang beradai di desa Baluase dalam prosesi perkawinan adat masih melaksanakan tradisi seperti, notate dala, neduta,nogero jene, mematua dan nokai botiga masih sering dilakukan. Pada malam sebelum besoknya dilaksanakan akad nikah, keluarga dan masyarakat berkumpul dirumah calon mempelai untuk melaksanakan do'a tahlil yang dikirimkan kepada arwah leluluhur dan pembacaan barzanji dengan tujuan prosesi tersebut mendapat berkah.

Sebagaimana disebutkan di atas, bahwa perkawinan itu bukan saja hanya merupakan suatu peristiwa penting tetapi termasuk juga merupakan peristiwa yang sangat berarti serta sepenuhnya mendapat perhatian dan di ikuti oleh arwah-arwah para leluhur dari kedua belah pihak. ${ }^{20}$ perhatian masyarakat adat terhadap leluhurnya pada saat dihubungkan dengan perkawinan dapat dilihat pada ritual dan kepercayaan yang berkaitan dengan tradisi perkawinan.

Pada pelaksanaan nikah nanau labe, prosesi perkawinan adat sebagaimana yang disebutkan diatas sudah tidak dilaksanakan, karena

${ }^{19}$ Ahlin, Tokoh Agama, wawancara di desa Baluase 26 Maret 2021 2015),, h. 207

${ }^{20}$ Tolib Setiady, Intisari Hukum Adat Indonesia dalam Kajian Kepustakaan (Bandung: Alfabeta, 
tujuan dari pernikahan tersebut hanya sekedar meperjelas status sekaligus menutupi aib pada keluarga. Sehubungan dengan pelaksanaan nikah nanau labe, Asri mengatakan bahwa:

Dalam pelaksanaan nikah nanau labe, berdasarkan hukum adat suku Kaili seharusnya nikah baru dapat dilaksanakan ketika sanksi adat sudah diberlakukan (moha tana). Pada saat berakhirnya akad nikah maka tidak diperkenankan bagi laki-laki untuk bermalam dirumah wanita termasuk melakukan ada nogero jene sebagaimana pada prosesi adat perkawinan suku kaili. Saksi adat bagi pelaku nikah nanau labe jika perbuatan tersebut dilakukan atas dasar suka-sama suka maka kedua pihak (laki-laki dan perempuan) wajib membayar sanksi adat (givu moha tana) menyerahkan dua ekor kambing untuk membersihkan kampung yang dikotori oleh zina. Proses pembayaran adat dilaksanakan di Bantaya (rumah adat) seteleh denda adat ditunaikan barulah proses pernikahan diserahkan kepada imam. Pelaksanaan nikah nanau labe sama seperti proses nikah biasa yang terpenuhi syarat dan rukunnya. Jika betul-betul mengikuti aturan adat pengantin laki-laki tidak boleh makan dirumah mempelai wanita setelah nikah dilaksanakan. Jadi nikah nanau labe adalah nikah yang bertujuan untuk penutup malu (aib) akibat hamilnya seorang wanita, dan proses perceraiannya bersamaan dengan hari pernikahan tepatnya setelah selesainya akad nikah yang ditandai dengan turunnya laki-laki dari rumah mempelai wanita setelah selesainya pernikahan. ${ }^{21}$

Berdasarkan keterangan dari informan dapat diketahui, bahwa sebelum pelaksanaan nikah nanau labe, laki-laki dan perempuan di perikasa guna mengetahui persoalan sebenarnya. Apabila dalam pemeriksaan terbukti bahwa terjadi pelanggaran adat maka sebelum dilaksanakan perkawinan pihak yang dianggap melakukan pelanggaran adat akan dikenakan sanksi adat (givu). Setelah dilaksanakan prosesi ijab kabul maka laki-laki yang menikahi perempuan tersebut turun dari rumah atau meninggalkan rumah pengantin wanita sebagai ketentuan dari nikah nanau labe. pada penelitian ini penulis juga menemukan perbedaan persepsi mengenai sanksi adat (givu ada) nikah nanau labe. perbandingan mengenai perbedaan persepsi tersebut dapat dilihat dari

${ }^{21}$ Asri, Orang Tua Adat (To Tua Ada ) Desa Baluase, wawancara, 22 Januari 2001, di Dolo Selatan Kabupaten Sigi 
keterangan yang disampaikan oleh salah satu pengurus lembaga adat di desa Baluase yang mengatakan bahwa:

Nikah nanau labe adalah pernikahan yang dasari karena hamilnya seorang wanita. pelaksanaan sanksi adat dalam nikah nanau labe tidak diberlakukan jika pasangan mau bertanggung jawab melaksanakan perkawinan dan dalam proses pemeriksaanya kepada si perempuan perlu dicari tahu apakah perbuatan tersebut dilakukan atas dasar suka sama suka, ada unsur pemaksaan, ataukah karena fitnah. apabila dalam kejadian tersebut terdapat unsur kekerasan karena terdapat luka maka hal tersebut dikategorikan sebagai perkosaan tetapi jika dalam perbuatan tersebut terdapat unsur kerja sama saling memudahkan untuk melakukan perbuatan maka perbuatan tersebut dikategorikan suka sama suka. Dalam nikah nanau labe, nasab keturunan seorang anak yang dikandung melekat pada lelaki yang menikahi perempuan tersebut, tetapi dalam urusan tanggung jawab nafkah kepada mantan istri sudah tidak ada sama sekali. seperangkat adat (sambulu biasa atau sambulu gana) pada prosesi perkawinan suku kaili sudah tidak diberlakukan lagi pada nikah nanau labe, jadi dalam pernikahan tersebut yang dibutuhkan hanya rukun dan syarat pernikahan dan dalam pelaksanaannya tanpa di isi dengan khutbah nikah. ${ }^{22}$

Pada keterangan informan sebelumnya (Asri) mengatakan bahwa sanksi adat dalam pernikahan nanau labe tetap dilaksanakan sebelum pernikahan karena adanya norma adat yang sudah dilanggar, tetapi dalam keterangan yang disampaikan oleh Mudin selaku pengurus lembaga adat didalam penjelasannya sudah tidak mengisyaratkan sanksi adat sebelum pelaksanaan nikah nanau labe yang penting permasalahan itu sudah selesai yaitu memastikan status anak yang akan lahir.

Penerapan sanksi adat pada nikah nanau labe di desa Baluase apabila dikaitkan dengan aturan dan sanksi adat suku Kaili di kota Palu maka sanksi adat berupa dua ekor kambing masih tergolong ringan. Sanksi adat berupa pembayan denda dengan menyerahkan kambing ini pada suku Kaili di kota Palu hanya dikategorikan dalam pelanggaran adat dalam kategori sedang (salah baba). Nikah nanau labe dapat terjadi karena adanya tindakan neduku dari seorang perempuan atau orang

${ }^{22}$ Mudin, Ketua Adat Desa Baluase, Waawancara, 25 Januari 2021 di Dolo Selatan Kabupaten Sigi 
tuanya yaitu dimana seorang perempuan turun dari rumah orang tuanya, lalu tinggal menetap di kediaman orang tua pihak laki-laki yang memang telah memiliki hubungan asmara, perbuatan ini dikategorikan sebagai tindakan pelanggaran adat berat (sala kana) bagi laki-laki dan kenakan sanksi adat (givu) satu ekor kerbau (sampomava bengga). ${ }^{23}$ Berdasarkan penjelasan di atas dapat kita lihat bahwa pemberlakuan sanksi adat pada nikah nanau labe di desa Baluase telah terjadi pergeseran.

Ada pun faktor utama yang melatarbelakangi terjadinya nikah nanau labe adalah pergaulan bebas yang mengakibatkan hamilnya perempuan di luar nikah sehingga harus di nikahkan dengan laki-laki lain jika kekasihnya tidak bertanggunggung jawab (menghilang) atau dinikahkan dengan pria yang menghamilinya, tetapi dilaksanakan dengan ketentuan nikah nanau labe karena ada sebab lain yang mempengaruhinya seperti komunikasi keluarga yang tidak tepat pada saat pengurusan perkawinan anak-anaknya sehingga membuat tersinggung pihak keluarga lainnya. sebagaimana informasi yang disampaikan oleh informan NF yang mengatakan bahwa:

Memang awalnya saya dan AZ ini pacaran tapi setelah itu putus. saya dan dia hilang kontak tidak ada saling menghubungi, tiba-tiba waktu ketemu dalam satu tempat dia bersama pacarnya dan saya dengan pacarku juga, waktu kami ketemu responnya biasa-biasa tanpa ada respon. Saat ketemu lagi dia datang menyampaikan bahwa dia hamil, setelah saya tanya-tanya dia bilang saya bukan pacarnya, saya kaget dan sempat tidak percaya kenapa saya dia bilang bukan percaya. Karena posisi perempuan dipercaya, jadi saya pasrah ba iyakan walaupun saya belum tahu itu anak saya atau bukan. Datang orang tuanya di rumah dan menyampaikan anaknya hamil karena saya, orang tua saya kaget. Saya disampaikan untuk bertanggungjawab, karena saya mempertimbangkan kekeluargaan akhirnya saya turuti. Begitu saya turuti rupanya bukan hanya itu keinginannya rupanya hanya membuat malu. Begitu diatur tanggal pernikahan saya diantar untuk dinikahkan. Setelah selesai ijab kabul pihak keluarga perempuan bertanya bagaimana sudah anak-anak ini, siapa yang suruh menikahkan anak ini, " setelah nikah itu pergi sudah, turun

${ }^{23}$ Timudin Dg. Mangera Bauwo dkk, Atura Nuada ante Givu Nuada to Kaili ri Livuto nu Palu. (HUkum dan Sanksi Adat Kaili di Palu), Badan Penelitian dan Pengembangan Daerah Provinsi Sulawesi Tengah Tahun 2012. 
sudah"akhirnya keluarga saya panas juga mendengar kata-kata itu, keluarga memutuskan turun dari rumah. Tapi setelah selesainya nikah itu saya tetap urus anak saya. ${ }^{24}$

Berdasarkan keterangan yang disampaikan oleh NF, dapat diketahui bahwa faktor yang melatarbelakangi nikah nanau labe yaitu Pergaulan bebas antara laki-laki dan perempuan, laki-laki yang menghamili menyangkal atau melarikan diri dan cara berkomunikasi keluarga pada saat menjelang atau dilaksanakannya akad nikah. Selain dari ketiga faktor tersebut oleh NS mengatakan bahwa faktor lain yang melatarbelakangi nikah nanau labe adalah sikap egois orang tua.

Waktu pelaksanaan pernikahan saya dan setelah ijab kabul dilaksanakan, orang tua perempuan meminta ketambahan harta hantaran dan dari keluarga kami tidak mampu memikul permintaan dari keluarga perempuan itu karena terlalu berlebihan. Saya disuruh turun dari rumah untuk mengusahakan permintaan itu dan kembali setelah permintaan itu sudah dipenuhi. karena berbulanbulan saya tidak bisa mengupayakan memikul permintaan itu, walaupun sebenarnya kami masih saling mencintai hanya saja orang tua yang sengaja memisahkan. Sebenarnya tidak ada ketentuannya kami bercerai sebabnya itu saja bahwa ada sesuatu yang dibebankan kepada saya tetapi saya tidak bisa memikul permintaan itu. Karena kedua keluarga sudah tidak berkomunikasi akhirnya kami sudah segan untuk ketemu dan sampai hari ini kami sudah memiliki pasangan hidup masing-masing walau pun tadinya tanpa kejelasan cerai, saya bingung bagaimana status pernikahan kami dari segi negara dan agama. ${ }^{25}$

Keterangan yang disampaikan NS mengenai nikah nanau labe dilatarbelakangi oleh sikap penolakan secara halus dari pihak keluarga perempuan dengan cara memberikan persyaratan tambahan setelah dilaksanakan ijab kabul, seharusnya kalaupun ada sesuatu yang kurang dari hantaran keluarga termasuk adat givu nika nanau labe sebaiknya dibicarakan sebelum pelaksanaan ijab Kabul untuk ditemukan solusinya apabila orang tua menginginkan keharmonisan pernikahan pada anakanaknya.

${ }^{24}$ NF, Pelaku Nikah Nanau Labe, wawancara di desa Baluase, 14 Maret 2021
${ }^{25}$ NS, Pelaku Nikah Nanau Labe, wawancara di desa Baluase, 17 Maret 2021 
Faktor lain yang melatarbelakangi nikah nanau labe adalah untuk memastikan agar anak yang akan dilahirkan memiliki ayah. Walaupun sebagaian masyarakat mempersepsikan bahwa pernikahan tersebut bertujuan untuk meng-Islamkan anak yang akan lahir. Sebagaimana keterangan yang disampaikan oleh tokoh agama desa Baluase mengenai persepsi sebagian masyarakat terhadap pelaksanaan nikah nanau labe.

Sebenarnya tujuan pernikahan itu adalah untuk membangun keluarga supaya hidup bersama- sama dimana laki-laki sebagai kepala rumah tangga dapat membimbing istri dan anaknya dengan pendidikan agama dan istri dapat berbakti kepada suami dan mengurus anak-anaknya. Nah dalam nikah nanau lebe ini memang hanya sebatas menikah tetapi setelah proses ijab kabul selesai lakilaki turun dari rumah perempuan sebagai tanda perkawinan sudah berakhir karena memang nikah nanau labe ini hanya sekedar mempertanggungjawabkan status anak yang dikandung si perempuan akibat hamil di luar nikah walaupun tadinya tujuan nikah tidak hanya sebatas itu. Kemudian di masyarakat ada juga yang beranggapan bahwa nikah nanau labe itu adalah nikah yang bertujuan untuk mengislamkan anak yang akan lahir. ${ }^{26}$

Keterangan yang sama juga di sampaikan oleh Sahrudin Hairi selaku Pelaksana Jabatan Kepala Desa Baluase yang mengatakan:

Di kampong ini masih ada ditemukan kasus nikah nanau labe. faktor yang malarbelakangi pernikahan tersebut adalah pergaulan bebas anak muda hingga larut malam dan kepercayaan keluarga untuk meng-Islamkan anak yang dilahirkan. Sehingga kami dari pemerintah desa apabila di undang untuk menghadiri pernikahan tersebut kami tidak hadir. ${ }^{27}$

Pada dasarnya setiap manusia sebelum terlahir ke dunia sudah dalam keadaan Islam dan suci, karena setiap manusia yang dilahirkan ke dunia sudah mengucapkan ikrar kepada Allah tentang Tuhannya sebagaimana yang dijelaskana dalan surah al A'raf ayat 172, sehingga pemahaman masyarakat terkait status agama anak yang lahir dalam nikah nanau labe belum beragama Islam perlu diluruskan.

2. Aspek Hukum Nikah Nanau Labe

${ }^{26}$ Sahrir, Tokoh Agama, wawancara di desa Baluase 22 Maret 2021 2021

${ }^{27}$ Sahrudin Hairi, pelaksana Jabatan Kepala Desa Baluase, wawancara di desa Baluase, 26 Maret 
Nikah nanau labe termasuk dalam kategori perkawinan yang tidak tercatat. Al-Qur'an dan Hadits tidak mengatur secara rinci mengenai pencatatan perkawinan, tetapi karena pentingnya sifat dari pencatatan perkawinan sehingga perlu diatur dalam untuk kepentingan administrasi perkawinan dan kependududkan.

Pencatatan perkawinan bertujuan untuk mewujudkan ketertiban perkawinan dalam masyarakat, baik perkawinan yang dilaksanakan berdasarkan hukum Islam, maupun perkawinan yang dilaksanakan oleh masyarakat yang tidak berdasarkan hukum Islam. Pencatatan perkawinan merupakan upaya untuk menjaga kesucian dan aspek hukum yang timbul dari ikatan perkawinan. Realisasi dari pencatatan perkawinan adalah akta nikah yang salinanannya dimiliki oleh suami istri. Akta nikah ini dapat digunakan oleh masing-masing pihak apabila ada yang merasa di rugikan dari adanya ikatan perkawinan tersebut guna agar mendapatkan haknya. ${ }^{28}$ Pasal 7 ayat (1) Kompilasi Hukum Islam di sebutkan bahwa perkawinan hanya dapat di buktikan dengan akta nikah yang dibuat oleh Pegawai Pencatat Nikah.

Pada nikah nanau labe pernikahan hanya dianggap sebagai upaya untuk menupi aib dari kehamian diluar nikah sekaligus menentukan status anak yang akan dilahirkan. Dalam hukum Administrasi pengakuan kepemilikan anak hanya dapat dibuktikan melalui akta kelahiran anak yang dalam proses pengurusannya menjadikan akta nikah sebagai salah satu syarat penerbitannya. Akta kelahiran bagi anak akan memberikan jaminan kepastian hukum bagi soarang anak mengenai hak-hak yang harus diperoleh dari orang tuanya sebagaimana yang dijelaskan dalam Kompilasi Hukum Islam Dengan demikian, apabila seorang anak dilahirkan tanpa memiliki kejelasan status kelahirannya maka dapat dipastikan akan ada hak-hak anak yang akan diabaikan seperti untuk mendapatkan biaya pendidikan dan pemeliharaan termasuk kepastian hukum yang berkaitan dengan warisan apabila ayahnya meninggal dunia.

${ }^{28}$ Zainudin Ali, op.cit, h. 26 
Pada Pasal 99 kompilasi Hukum Islam disebutkan bahwa anak sah adalah anak yang dilahirkan dalam atau akibat perkawinan yang sah atau melalui hasil pembuahan suami istri yang sah diluar rahim dan dilahirkan oleh istri tersebut. Selanjutnya pada Pasal 100 semakin di pertegas bahwa anak yang lahir di luar perkawinan hanya mempunyai nasab dengan ibunya dan keluarga ibunya. Pasal 152 disebutkan, bekas istri berhak mendapat nafkah iddah dari bekas suaminya kecuali bila ia nusyuz. Dengan demikian pelaksanaan nikah nanau labe antara perempuan yang hamil dan lelaki yang menghamilinya, apabila mengabaikan proses administrasi perkawinan maka akan merugikan wanita tersebut dan anak yang berada dalam kandungannya. Berdasarkan Pasal 6 ayat (2) Kompilasi Hukum Islam yang menyebutkan, bahwa perkawinan yang dilakukan diluar pengawasan Pegawai Pencata Nikah tidak mempunyai kekuatan hukum, maka pasangan yang akan melaksanakan nikah nanau labe termasuk kedua kedua keluarga perlu mempertimbangkan masalah tersebut demi kemaslahatan bersama.

Secara agama nikah nanau labe adalah nikah yang memperhatikan rukun dan syarat dalam pernikahan, hanya saja yang menjadi persoalan apakah boleh menurut ulama menikahi perempuan hamil akibat perzinahan dan menikahi perempuan hamil bukan hasil zina, dibawah ini akan diuraikan masalah tersebut berdasarkan pendapat ulama mazhab yang diuraikan segai berikut:29

\section{a. Mazhab Hanafi}

Mazhab Hanafi berpendapat, jika perempuan yang dizinai tidak hamil, maka sah akad perkawinan kepadanya dari laki-laki yang tidak melakukan zina kepadanya. Begitu juga jika dia hamil akibat perbuatan zina tersebut maka dia boleh dinikahi, menurut Abu Hanifah dan Muhammad. Akan tetapi, dia tidak di gauli sampai dia melahirkan anaknya.

${ }^{29}$ Wahbah Az-Zuhaili, Fiqih Islam Wa Adillatuhu, jilid 9 ed. Terjemahan (Jakarta: Gema Insani, 2011), h. $144-146$ 


\section{b. Mazhab Maliki}

Mazhab Maliki berpendapat, tidak boleh dilaksanakan akad terhadap perempuan yang melakukan perbuatan zina sebelum dia dibebaskan dari zina dengan tiga kali haid atau telah lewat masa tiga bulan. Jika dilaksanakan akad pernikahan kepadanya sebelum dia dibebaskan dari zina, maka akad pernikahan ini adalah sebuah akad yang fasid. Akad ini harus dibatalkan, baik muncul kehamilan atau tidak.

c. Mazhab Syafi'i

Mazhab Syafi'i berpendapat, jika dia melakukan hubungan zina dengan seorang perempuan, maka tidak haram baginya untuk menikahinya. Ketentuan ini berlaku pada perempuan dan laki-laki yang melakukan zina.

d. Mazhab Hambali

Mazhab Hambali berpendapat, jika seorang perempuan melakukan perbuatan zina, maka bagi orang yang mengetahui hal itu tidak boleh menikahinya, kecuali dengan dua syarat, yaitu:

1. Masa iddahnya telah selesai. Jika dia hamil akibat perbuatan zina, maka berakhirnya masa iddahnya adalah dengan melahirkan anaknya dan dia tidak boleh dinikahi sebelum dia melahirkan anaknya.

2. Dia bertobat dari perbuatan zina.

\section{Penutup}

Berdasarkan urain dan penjelasan dari penelitian di atas penulis menarik kesimpulan sebagai berikut:

1. Pelaksanaan Nikah nanau labe diberlakukan kepada wanita yang hamil diluar nikah kemudian dinikahkan dengan laki-laki yang bersedia menikahinya apabila laki-laki yang menghamili perempuan tersebut tidak bertanggung jawab atau melarikan diri, nikah nanau labe juga dapat terjadi apabila laki-laki yang menghamilinya bertanggung jawab tetapi pernikahan nanau labe tetap dilaksanakan karena adanya faktor-faktor lain yang memicunya. 
Sebelum pelaksanaan nikah nanau labe seharusnya sanksi adat tetap diberlakukan tetapi di desa Baluase denda adat dalam nikah nanau labe sudah tidak berlaku. Ada pun faktor-faktor yang melatar belakangi nikah nanau labe di desa Baluase yaitu pergaulan bebas sehingga mengakibatkan kehamilan, laki-laki yang menghimili perempuan tidak bertanggung jawab, komunikasi keluarga yang tidak tepat, sikap egois orang tua, memastikan status anak yang lahir.

2. Aspek hukum yang timbul akibat nikah nanau labe adalah tidak terjaminnya kepastian hukum dari perkawinan tersebut, sehingga wanita tidak mendapatkan hak-haknya setelah perceraian sebagaimana yang disebutkan dalam Pasal 6 ayat (2) dan Pasal 152 Kompilasi Hukum Islam. Nikah nanau labe merugikan hak-hak anak karena tidak ada jaminan pemberian biaya pemeliharaan dan pendidikan anak dari ayah kepada anaknya, selanjutnya nikah nanau labe juga dapat merugikan anak karena tidak memiliki kepastian hukum dalam pengurusan administrasi kelahiran sebagaimana Pasal 99 Kompilasi Hukum Islam. Dalam aspek keperdataan, seorang anak tidak mendapatkan hak waris dari ayahnya apabila meninggal dunia sebagaimana disebutkan dalam Pasal 186 Kompilasi Hukum Islam, anak yang lahir di luar perkawinan hanya mempunyai hubungan saling mewaris dengan ibunya dan keluarga dari pihak ibunya. Perkawinan yang sah menurut Kompilasi Hukum Islam adalah perkawinan yang dilakukan menrut hukum Islam sesuai dengan Pasal 2 ayat (1) UndangUndang nomor 1 Tahun 1974 tentang Perkawinan. Selanjutnya nikah nanau labe boleh dilakukan apabila didasarkan pada pendapat Mazhab Hanafi tentang kebolehan menikahi perempuan hamil akibat perzinahan dan menikahi perempuan hamil bukan hasil zina tetapi harus memperhatikan ketentuan-ketentuan yang membatasinya. 


\section{Daftar Pustaka}

Abdul Hamid, Kahi' Pura Sebagai Perkawinan Passampo Siri' di Desa Biji Nangka Kecamatan Sinjai Borong Kabupaten Sinjai. https://ojs.unm.ac.id/tomalebbi/article/view/3663/2079 diakses pada tanggal 19 Januari 2021

Abu Abdullah Muhammad bin Ismail Al Bukhari, Shahih Bukhari Juz 1, Terj. Achmad Sunarto, dkk, Tarjamah Shahih Bukhari Jilid 1. Semarang: CV. Asy Syifa', 1991.

Ahmad Azhar Basyir, Hukum Perkawina Islam. Yogyakarta, UII Pres, 2000.

Amir Syarifuddin, Garis-Garis Besar Fiqih. Jakarta: Kencana Prenada Media,2003.

Departemen Pendidikan dan Kebudayaan, Kamus Besar Bahasa Indonesia. Jakarta: Kencana,1994

H.S.A. Al Hamdani, Risalah Nikah. cet 3; Jakarta: Pustaka Aman, 1998

Khoiruddin Nasution, Hukum Perdata (keluarga) Islam Indonesia dan Perbandingan Hukum Perkawinan di Dunia Muslim. Yogyakarta: ACAdeMIA.

Departemen Agama Republik Indonesia, Al-Qur'an dan Terjemahnya, Jakarta: al Hidayah, 2002

Muhyidin, Nikah Mut'ah (kawin kontrak) dalam Perspektif Hukum Positif Indonesia Serta Akibat Hukum Atas Harta Perkawinan dan Harta Waris. (http://ejournal2.undip.ac.id/index.php/dplr/article/download/8180/4302\#: : text+kawin\%20kontrak\%20merupakan\%20perkawinan\%20yang,1\%20Tah un\%201974\%20tentang\%20Perkawinan) diakses pada tanggal 19 Januari 2021

R. Abdul Djamali, Hukum Islam. Bandung: Mandar Maju, 2000

Rahmat Hakim, Hukum Perkawinan Islam untuk IAIN, STAIN, PTAIS. Bandung: CV Pustaka Setia, 2000.

Sayyid Sabiq, Fiqh al-Sunnah. Beirut: Dar al-Fikr, 1983, cet. 4 jilid 2.

Satria Efendi, Ushul Fiqh. Jakarta: Kencana, 2005.

Suriyaman Mustari, Hukum Adat Dahulu Kini dan Akan Datang. Jakarta: Kencana, 2014. 
Timudin Dg. Mangera Bauwo dkk, Atura Nuada ante Givu Nuada to Kaili ri Livuto nu Palu. (HUkum dan Sanksi Adat Kaili di Palu), Badan Penelitian dan Pengembangan Daerah Provinsi Sulawesi Tengah Tahun 2012.

Tolib Setiady, Intisari Hukum Adat Indonesia dalam Kajian Kepustakaan. Bandung: Alfabeta, 2015.

Wahbah Az-Zuhaili, Fiqih Islam Wa Adillatuhu, jilid 9 ed. Terjemahan. Jakarta: Gema Insani, 2011.

Zainuddin Ali, Hukum Perdata Islam di Indonesia. Jakarta: Sinar Grafika, 2007. 